\title{
Nurses - Midwives' Knowledge concerning Pap Smear in Baghdad city Hospitals
}

\author{
*Ahrar M. Rashied, **Iqbal Majeed Abbas Prof. PhD. \\ M.Sc.N - Academic Nurse Specialist, Ministry of Health, Al Yarmook Teaching Hospital. \\ Maternal and Child Health Nursing Department, College of Nursing, University of Baghdad, Iraq
}

\begin{abstract}
Background: Cervical cancer is one of the leading causes of morbidity and mortality amongst the gynecological cancers worldwide, Cervical cancer is potentially preventable, and through effective screening programs can lead to reduction in the morbidity and mortality associated with this cancer.

Objective: The study aimed to assess nurses-midwives' knowledge concerning the pap smear and determine the association between nurse-midwives' knowledge and their demographic, reproductive variables in Baghdad city Hospitals.

Methodology: A descriptive analytical study was carried out from September/ 1/2013 to December /30/ 2013 through a "non-probability" purposive sample of (170) nurse-midwives which was selected from (9) hospitals in Baghdad city, The data were collected by the investigator who interviewed the nurse - midwives and filled out the constructed a questionnaire formats which designed for the purpose of the study and comprised of two main parts: part one including: demographic, reproductive, nursing, midwifery experience and pap smear training course variables, part two including: knowledge concerning pap smear. The validity of the questionnaire was determined through a panel of experts in the specialist fields while the reliability of the questionnaire was determined by calculating the Reliability coefficient. Thereafter, the data were analyzed through the application of descriptive and inferential statistics approach.

Results: The study findings indicated that most of the nurse-midwives' knowledge concerning pap smear test unacceptable, there were low mean of score in all items of nurse- midwives knowledge, there were no statistical significant association between nurses -midwives' knowledge concerning pap smear and their demographic, reproductive variables, their experience, pap smear course and duration of training course.

Conclusion: There were unacceptable results of nurse - midwives' knowledge concerning Pap smear and majority of nurse - midwives hadn't adequate knowledge which can affect the type of care concerning Pap smear.

Recommendations: The study recommends that need for advanced education and training course for nurses midwives and other health care providers concerning pap smear to increase knowledge and awareness and reactivate national screening program guidelines at best.
\end{abstract}

Key words: - Assessment, knowledge, Nurses - Midwives and pap smear.

\section{INTRODUCTION}

Cervical cancer is a preventable disease. The natural history of cervical cancer reveals that it has great potential for prevention and cure as it slowly progresses through several stages of precancerous intra epithelial lesions before developing into an invasive form. This characteristic associated to the relatively easy diagnosis allows detecting this disease at early stages when treatment results in high cure rates ${ }^{(1)}$. In many of the developed countries the annual incidence and mortality from this cancer has gone down by $50-70 \%$ since the introduction of population based screening ${ }^{(2)}$. The most efficient treatment method in cancer is to catch the disease early and make an early diagnosis. Early diagnosis and treatment is quite important in reducing the mortality of the cervix cancer. Pap smear test, which is used in the early diagnosis of cervix cancer, is a test which is easy to apply, inexpensive, not harmful, highly sensitive and it decreases treatment burden, morbidity and mortality ${ }^{(3)}$.

It was demonstrated that all women, whether healthy or ill, can easily establish communication with midwives and nurses on the health care team, who are in closest, longest contact with both diseased and healthy individuals within the society. Because they are both women themselves and easily accessible, nurse-midwives hold a key position in education and counseling services ${ }^{(4)}$.A study revealed that for these reasons, So nursemidwives need to have good theoretical knowledge of cervical cancer and pap smear test, regardless of their field of expertise ${ }^{(5)}$. Nurses are the most visible, frontline personnel providing health education to patients and the general population. Because nurses and midwives play an integral role in educating women in prevention of diseases and health promotion, they influence cervical cancer screening adherence and health activities among most women. Moreover, it has been shown that recommendation of cervical cancer screening to individuals by 
medical professionals, including nurses, effectively improves screening coverage among the general population ${ }^{(6)}$.Therefore, nurses and midwives should have current and accurate knowledge about pap smear and cervical cancer to promote informed decisions about cervical cancer screening. So the objectives of the study are to assess the nurse-midwives' knowledge concerning pap smear and determine the association between nursemidwives' knowledge related pap smear and their demographic \& reproductive variables in Baghdad city hospitals.

\section{METHODOLOGY}

A descriptive analytical design was carried out from $1^{\text {st }}$ September 2013 to $30^{\text {th }}$ December 2013, a purposive "non-probability" sample of (170) Nurse- Midwives which was selected from (9) hospitals in Baghdad city. From Al-Karkh/Health Directorate (4) hospitals including: Al- Kahadymia Teaching Hospital, Al-Yarmok Teaching Hospital ,Al-Karkh Maternity Hospital, Al- Karama teaching Hospital. and from AlRussafa / Health Directorate (5) hospitals including: Al- Elwia Maternity Teaching Hospital, Fatema Al-Zahra Maternity and Pediatric Hospital, Ibn-Al- Balidy Maternity and Pediatric Hospital, Al-Numan Teaching Hospital and Baghdad Teaching Hospital. The data were collected by the investigators who interviewed the nurse-midwives and filled out the constructed a questionnaire formats which designed for the purpose of the study, so calculate accepted knowledge is ( equal or more than 31.5) while unaccepted knowledge is ( less than 31.5) through following formula: number of items $(21) *$ cut of point $(1.5)=31.5$, The questionnaire comprised of two main parts: first part including demographic, and reproductive the second part including knowledge of pap smear among study sample which consist of (21) items related to knowledge. The validity of the questionnaire was determined through (14) a panel of experts in the specialist fields while; the reliability of the questionnaire was determined to calculate the reliability coefficient. the researcher used appropriate statistical approach through the application of descriptive analysis measures (frequencies and percentages) and inferential statistics approach (Chi-Square) the data were analyzed through the use of Statistical Package of Social Science (SPSS) version 16.0.

\section{THE RESULTS}

Table (1) Distribution of nurses- midwives according to their socio-demographic, reproductive variables ( $\mathrm{N}$ $=170)$.

\begin{tabular}{|c|c|c|}
\hline Variables & No. & $\%$ \\
\hline \multicolumn{3}{|l|}{ Age / years } \\
\hline $20-29$ & 29 & 17.1 \\
\hline $30-39$ & 47 & 27.6 \\
\hline $40-49$ & 70 & 41.2 \\
\hline 50 and above & 24 & 14.1 \\
\hline \multicolumn{3}{|l|}{ Educational Level } \\
\hline Nursing school & 34 & 20.0 \\
\hline Secondary nursing school graduate & 37 & 21.8 \\
\hline Midwifery secondary school graduate & 68 & 40.0 \\
\hline Nursing \& Midwifery institute graduate & 21 & 12.3 \\
\hline College of nursing & 10 & 5.8 \\
\hline \multicolumn{3}{|l|}{ Marital Status } \\
\hline Married & 132 & 77.7 \\
\hline Widow & 13 & 7.6 \\
\hline Separate & 7 & 4.1 \\
\hline Divorced & 18 & 10.6 \\
\hline \multicolumn{3}{|l|}{ Income status } \\
\hline Enough & 26 & 15.3 \\
\hline No enough & 92 & 54.1 \\
\hline Enough Approximately & 52 & 30.6 \\
\hline \multicolumn{3}{|l|}{ Number of Gravida } \\
\hline None & 15 & 8.8 \\
\hline Equal or less than 4 gravida & 96 & 56.5 \\
\hline Equal or more than 5 gravida & 59 & 34.7 \\
\hline \multicolumn{3}{|l|}{ Number of Para } \\
\hline None & 24 & 14.1 \\
\hline $1-4$ para & 113 & 66.5 \\
\hline $5 \&$ above & 33 & 19.4 \\
\hline \multicolumn{3}{|l|}{ Having previous abortion } \\
\hline Yes & 89 & 52.4 \\
\hline No & 81 & 47.6 \\
\hline
\end{tabular}


Nurses - Midwives' Knowledge concerning Pap Smear in Baghdad city Hospitals

\begin{tabular}{|l|c|c|}
\hline Family history of cancer & \multicolumn{2}{|l|}{} \\
\hline Yes & 37 & 21.8 \\
\hline No & 133 & $\mathbf{7 8 . 2}$ \\
\hline Total & 170 & $100 \%$ \\
\hline
\end{tabular}

Table (1) demonstrate that highest percentage (41.2\%) of them were in the age of (40 - 49 ) years $(40.0 \%)$ were midwifery secondary school graduate, $(77.7 \%)$ were married, $(54.1 \%)$ had not enough income, $(56.5 \%)$ have four and less gravida, $(66.5 \%)$ had one to five para , $(52.4 \%)$ were having previous abortion, and $(78.2 \%)$ of them haven't family history of cancer.

Table (2) Distribution of nurses - midwives according their experience, pap smear course and duration of training course $(\mathrm{N}=170)$.

\begin{tabular}{|c|c|c|}
\hline variables & \multirow{2}{*}{ NO } & \multirow{2}{*}{$\%$} \\
\hline Nursing experience ( year ) & & \\
\hline None & 14 & 8.2 \\
\hline Less than 1 year & 14 & 8.2 \\
\hline $1-5$ years & 64 & 37.7 \\
\hline $6-10$ years & 31 & 18.2 \\
\hline 11 years and above & 47 & 27.7 \\
\hline \multicolumn{3}{|l|}{ Midwifery experience ( year ) } \\
\hline None & 60 & 35.3 \\
\hline Less than 1 year & 23 & 13.5 \\
\hline $1-5$ years & 49 & 28.8 \\
\hline $6-10$ years & 14 & 8.2 \\
\hline 11 years and above & 24 & 14.2 \\
\hline \multicolumn{3}{|l|}{ Pap smear course } \\
\hline Yes & 5 & 2.9 \\
\hline No & 165 & 97.1 \\
\hline \multicolumn{3}{|c|}{ Duration the training course of pap smear } \\
\hline One week & 4 & 80 \\
\hline Two weeks & 1 & 20 \\
\hline Total & 170 & $100 \%$ \\
\hline
\end{tabular}

Table (2) show that highest percentage of nurse- midwives $(37.7 \%)$ were having (1 - 5 years) of nursing experience, $(35.3 \%)$ didn't have midwifery experience, $(97.1 \%)$ didn't have pap smear course, while highest percentage $(80 \%)$ of them have one week duration of training course related to pap smear.

Table (3) Level of knowledge regarding Pap Smear among the sample of (170) nurses - midwives.

\begin{tabular}{|l|l|c|c|c|c|c|}
\hline \multirow{2}{*}{ no. } & \multicolumn{1}{|c|}{ Knowledge regarding Pap Smear } & \multicolumn{2}{|c|}{ Yes } & \multicolumn{2}{c|}{ No } & \multirow{2}{*}{ MS. } \\
\cline { 3 - 5 } & & No. & $\%$ & No. & $\%$ & \\
\hline $1-$ & Did you hear about pap smear & 12 & 7.0 & 158 & 92.9 & 1.07 \\
\hline $2-$ & Did pap smear scraping cervical cells & 84 & 49.4 & 86 & 50.5 & 1.49 \\
\hline $3-$ & Pap smear able to detect precancerous cell & 33 & 19.4 & 137 & 80.5 & 1.19 \\
\hline $4-$ & Early detection chance curing the cervical disease & 18 & 10.5 & 152 & 89.4 & 1.10 \\
\hline $5-$ & It detect the fibroids tumor & 40 & 23.5 & 130 & 76.4 & 1.76 \\
\hline $6-$ & It reduce mortality \& mortality of cervical cancer & 25 & 14.7 & 145 & 85.2 & 1.14 \\
\hline $7-$ & It used in starting onset of married & 101 & 59.4 & 69 & 40.5 & 1.59 \\
\hline $8-$ & It used after 2 weeks of menstrual period & 44 & 25.8 & 126 & 74.1 & 1.25 \\
\hline $9-$ & It starting at age 21 & 50 & 29.4 & 120 & 70.5 & 1.29 \\
\hline $10-$ & It doing every 3years in reproductive age & 65 & 38.5 & 105 & 61.7 & 1.38 \\
\hline $11-$ & Women need pap smear after menopause & 38 & 22.3 & 132 & 77.6 & 1.22 \\
\hline $12-$ & $\begin{array}{l}\text { Woman need pap smear after hysterectomy for any } \\
\text { causes }\end{array}$ & 86 & 50.5 & 84 & 49.4 & 1.49 \\
\hline $13-$ & $\begin{array}{l}\text { Woman need pap when metrorrhagea and menorrhagea } \\
\text { occurred }\end{array}$ & 47 & 27.6 & 123 & 72.3 & 1.2 \\
\hline $14-$ & Woman need pap in pain during sex & 49 & 28.8 & 121 & 71.1 & 1.28 \\
\hline $15-$ & Woman need pap in polymenorrhea & 45 & 26.4 & 125 & 76.5 & 1.26 \\
\hline $16-$ & In weak immune repeat the pap smear & 22.3 & 132 & 77.6 & 1.22 \\
\hline
\end{tabular}


Nurses - Midwives' Knowledge concerning Pap Smear in Baghdad city Hospitals

\begin{tabular}{|l|l|c|c|c|c|c|}
\hline $17-$ & It used 48 hours after sex & 51 & 30.0 & 119 & 70.0 & 1.30 \\
\hline $18-$ & It used 48 hours after vaginal bathing & 32 & 18.8 & 138 & 81.1 & 1.18 \\
\hline $19-$ & It used 72 hours after vaginal contraceptive & 38 & 22.3 & 132 & 77.6 & 1.22 \\
\hline $20-$ & It used even after HPV vaccine & 31 & 18.2 & 139 & 81.7 & 1.18 \\
\hline $21-$ & It is method of cervical cancer prevention & 14 & 8.2 & 156 & 91.7 & 1.08 \\
\hline
\end{tabular}

Table ( 3 ) show that there were low mean of scores in all items of nurse - midwives knowledge according pap smear $(\mathrm{N}=170)$.

Table ( 4A ) Association between nurses - midwives level of knowledge concerning pap smear and their demographic and reproductive variables

\begin{tabular}{|c|c|c|c|c|c|c|}
\hline \multirow{2}{*}{\multicolumn{2}{|c|}{$\begin{array}{l}\text { Variables } \\
\text { 1- Demographic variables }\end{array}$}} & \multicolumn{2}{|c|}{ Knowledge of Nurse- Midwives } & \multirow{2}{*}{$\begin{array}{c}\text { Sign } \\
\text { value }\end{array}$} & \multirow[t]{2}{*}{ d.f. } & \multirow[t]{2}{*}{ p-value } \\
\hline & & Acceptable & Unacceptable & & & \\
\hline \multirow{4}{*}{ Age/years } & 20-29 Years & 12 & 17 & \multirow{4}{*}{$\begin{array}{l}\chi^{2}= \\
4.22\end{array}$} & \multirow{4}{*}{3} & \multirow{4}{*}{$\begin{array}{l}0.238 \\
(\mathrm{NS})\end{array}$} \\
\hline & 30-39 Years & 27 & 20 & & & \\
\hline & 40-49 Years & 39 & 31 & & & \\
\hline & 50 and above & 9 & 15 & & & \\
\hline \multirow{4}{*}{$\begin{array}{c}\text { Educational } \\
\text { Level }\end{array}$} & Nursing school & 16 & 19 & \multirow{4}{*}{$\begin{array}{c}\chi^{2}= \\
4.078\end{array}$} & \multirow{4}{*}{3} & \multirow{4}{*}{$\begin{array}{l}0.253 \\
\text { ( NS ) }\end{array}$} \\
\hline & Secondary school & 59 & 54 & & & \\
\hline & Medical technique institute & 9 & 12 & & & \\
\hline & College of Nursing & 3 & 7 & & & \\
\hline \multirow{4}{*}{$\begin{array}{l}\text { Marital } \\
\text { Status }\end{array}$} & Married & 68 & 64 & \multirow{4}{*}{$\begin{array}{c}\chi^{2}= \\
4.095\end{array}$} & \multirow{4}{*}{3} & \multirow{4}{*}{$\begin{array}{l}0.251 \\
(\mathrm{NS})\end{array}$} \\
\hline & Widow & 4 & 9 & & & \\
\hline & Separate & 3 & 4 & & & \\
\hline & Divorced & 12 & 6 & & & \\
\hline \multirow{2}{*}{$\begin{array}{l}\text { Income } \\
\text { status }\end{array}$} & Enough & 50 & 41 & \multirow{2}{*}{$\begin{array}{c}\chi^{2}= \\
1.113\end{array}$} & \multirow[b]{2}{*}{1} & \multirow[b]{2}{*}{$\begin{array}{l}0.291 \\
\text { (NS ) }\end{array}$} \\
\hline & No enough & 37 & 42 & & & \\
\hline \multicolumn{7}{|c|}{ 2- Reproductive Variables } \\
\hline \multirow{3}{*}{$\begin{array}{l}\text { No. of } \\
\text { Gravida }\end{array}$} & None & 6 & 9 & \multirow{3}{*}{$\begin{array}{c}\chi^{2}= \\
0.826\end{array}$} & \multirow{3}{*}{2} & \multirow{3}{*}{$\begin{array}{c}0.662 \mathrm{~N} \\
(\mathrm{~S})\end{array}$} \\
\hline & Equal or less than 4 gravid & 50 & 46 & & & \\
\hline & Equal or more than 5 gravida & 31 & 28 & & & \\
\hline \multirow{3}{*}{ No. of Para } & None & 9 & 15 & \multirow{3}{*}{$\begin{array}{c}\chi^{2}= \\
2.113\end{array}$} & \multirow{3}{*}{2} & \multirow{3}{*}{$\begin{array}{l}0.348 \\
\text { (NS) }\end{array}$} \\
\hline & $1-4$ para & 60 & 53 & & & \\
\hline & $5 \&$ above & 18 & 15 & & & \\
\hline \multirow{2}{*}{$\begin{array}{l}\text { Previous } \\
\text { abortion }\end{array}$} & Yes & 46 & 43 & \multirow{2}{*}{$\begin{array}{c}\chi^{2}= \\
0.019\end{array}$} & 1 & 0.889 \\
\hline & No & 41 & 40 & & 1 & (NS ) \\
\hline Family & Yes & 18 & 19 & & & \\
\hline $\begin{array}{l}\text { history of } \\
\text { Cancer }\end{array}$ & No & 69 & 64 & $\begin{array}{c}\chi= \\
0.121\end{array}$ & 1 & $\begin{array}{l}0.128 \\
\text { (NS) }\end{array}$ \\
\hline
\end{tabular}

Table No. (4A) shows that there were no statistical significant association between nurses -midwives' knowledge concerning pap smear and their demographic \& reproductive variables.

Table ( 4B ) Association between nurses - midwives' knowledge concerning pap smear and their experience, pap smear course and duration of training course. $(\mathrm{N}=170)$

\begin{tabular}{|c|c|c|c|c|c|c|}
\hline \multirow{2}{*}{\multicolumn{2}{|c|}{ Variables }} & \multicolumn{2}{|c|}{ Knowledge of Nurse- Midwives } & \multirow{2}{*}{$\begin{array}{l}\text { Sign. } \\
\text { value }\end{array}$} & \multirow{2}{*}{ d.f. } & \multirow{2}{*}{ p-value } \\
\hline & & Acceptable & Unacceptable & & & \\
\hline \multirow{2}{*}{$\begin{array}{c}\text { Nursing } \\
\text { experience } \\
\text { (year) }\end{array}$} & Equal or less than 5 years & 44 & 48 & \multirow{2}{*}{$\begin{array}{c}\chi^{2}= \\
0.901\end{array}$} & \multirow[b]{2}{*}{1} & \multirow{2}{*}{$\begin{array}{c}0.343 \\
\text { ( NS ) }\end{array}$} \\
\hline & More than 5 years & 43 & 35 & & & \\
\hline \multirow{2}{*}{$\begin{array}{c}\text { Midwifery } \\
\text { experience } \\
\text { (year) }\end{array}$} & Equal or less than 5 years & 70 & 62 & \multirow{2}{*}{$\begin{array}{c}\chi^{2}= \\
0.812\end{array}$} & \multirow{2}{*}{1} & \multirow[b]{2}{*}{$\begin{array}{l}\mathbf{0 . 3 6 7} \\
\text { ( NS ) }\end{array}$} \\
\hline & More than 5 years & 17 & 21 & & & \\
\hline \multirow{2}{*}{$\begin{array}{l}\text { Pap Smear } \\
\text { course }\end{array}$} & Yes & 3 & 2 & \multirow{2}{*}{$\begin{array}{c}\chi^{2}= \\
0.161\end{array}$} & \multirow[b]{2}{*}{1} & \multirow{2}{*}{$\begin{array}{l}\text { 0.689 } \\
\text { ( NS ) }\end{array}$} \\
\hline & No & 84 & 81 & & & \\
\hline \multirow{3}{*}{$\begin{array}{l}\text { Duration } \\
\text { training course }\end{array}$} & None & 84 & 81 & \multirow{3}{*}{$\begin{array}{c}\chi^{2}= \\
1.962\end{array}$} & \multirow{3}{*}{2} & \multirow{3}{*}{$\begin{array}{l}0.375 \\
\text { (NS) }\end{array}$} \\
\hline & One week & 3 & 1 & & & \\
\hline & Two weeks & $\mathbf{0}$ & 1 & & & \\
\hline
\end{tabular}


Table No. (4B ) shows that there were no statistical significant association between nurse - midwives knowledge concerning pap smear in all items and their experience, pap smear course and duration of training course.

\section{DISCUSSION}

The findings of the study demonstrate that highest percentage of nurse- midwives (41.2) were in the age of $(40-49)$ years, $(77.7 \%)$ married, $(40.0 \%)$ midwifery secondary school graduate. The finding of the study demonstrate ( $56.5 \%$ ) have four and less gravida, ( $66.5 \%$ ) had one to five para, $(52.4 \%)$ having previous abortion, ( $78.2 \%$ ) didn't have family history of cancer as shown in table (1). The finding of the study demonstrate that highest percentage of nurse- midwives $(37.7 \%)$ were having (1-5 years) of nursing experience, $(35.3 \%)$ didn't have midwifery experience, $(97.1 \%)$ didn't have pap smear course, while highest percentage $(80 \%)$ of them have one week duration the training course of pap smear show in table (2).

According to the level of knowledge regarding pap smear there were low mean of scores in all items regarding nurses - midwives' knowledge about pap smear as show in table (3). These results were unacceptable for the nurse - midwives who working in the maternity department and contact with most of ill or healthy women who need their counseling and education and affecting on the care which introducing to the community. The finding of Present study supported evidence is available in the study that reported (66) midwives in Switzerland found that they did not have adequate information on cervical cancer and screening (7\&8). Likewise the result of a study revealed that high proportion of midwives lacking appropriate knowledge is mainly due to the difficulty of access information. Thus, expanding access to information by organizing seminars and training sessions specifically designed for health team or nurses and midwifery in all types of health facilities could significantly increase the proportion of midwives with adequate knowledge on cervical cancer prevention ${ }^{(9)}$.

Regarding the association between nurse - midwives level of knowledge concerning pap smear and their demographic and reproductive variables, there were no statistical significant association between nurses midwives knowledge concerning pap smear and their demographic variables (Age, educational level and marital status, income status) and reproductive variables ( number of gravida, number of Para, previous abortion and family history of cancer) show in table (4A). Almost of the nurse- midwives have unacceptable level of knowledge according pap smear, most of the study participant ( $92.9 \%$ ) didn't hear about pap smear, while only $(7 \%)$ hearing about pap smear, the nurse- midwives play an important roles as a health educator and a counselor. Therefore, unacceptable knowledge and low compliance with screening recommendations may lead to negative impact on community in undergoing a pap smear.

Regarding age group : There was no significant association between age group and knowledge of nurses- midwives concerning pap smear as show in ( Table 4A). In agreement with a study which reported that there were no significant differences between knowledge of nurse about cervical cancer risk factors or symptoms and screening methods regarding age $(\mathrm{p}>0.05)^{(10)}$. While that contrast with a study which was found a significant association between age and knowledge $(\mathrm{p}<0.05)^{(11)}$.

Regarding level of education : There were no significant association between level of education and knowledge of nurses - midwives concerning pap smear show in (Table 4A ). That is agreement with a study found level of education of nurses not associated with level of knowledge ${ }^{(11)}$. While contrast with the study which reported that there was a statistically significant relationship was found between knowledge of the nursemidwives about cervical cancer and their educational status $(\mathrm{p}<0.05){ }^{(12)}$.

Regarding marital status: there were no significant association between marital status and knowledge of nurses - midwives concerning pap smear as shown in (Table 4A). That means even the marital status not relation to the nurse - midwives' knowledge concerning Pap smear. That contrast with study revealed that this statistically significant difference was created by the married participants. This finding was connected to the fact that married women care more about the early diagnosis of cervical cancer due to having regular sexual activities, may have more gynecological complaints such as abortion and they may have applied to woman labor clinics more ${ }^{(13)}$.

Regarding income status: there were no significant association between income status of nursesmidwives and knowledge concerning pap smear as shown in (Table 4A ). In contrast with a study reported that the women in poor and minority communities have been identified as being less likely to utilize screening by pap smears and they are less likely to follow up after an abnormal Pap smear ${ }^{(14)}$.

Regarding number of gravida, Para, previous abortion: there were no significant association between number of gravida, Para, previous abortion and nurses- midwives' knowledge concerning pap smear as shown in (table 4A). Regarding family history of cancer: there were no significant association between family history of cancer and nurse- midwives' knowledge concerning Pap smear show in (table 4A). That contract with the study reported that there were a statistically relationship was determined between having received nurse a pap test and having a history of cancer in their family $(\mathrm{p}<0.05){ }^{(10)}$. 
Regarding the association between nurse - midwives knowledge concerning pap smear and their experience, pap smear course, there were no statistical significant association between nurse - midwives' knowledge concerning pap smear in all variables ( nursing experience, midwifery experience, pap smear course and duration of training course) show in table (4B ). That agreement with the study revealed that there were no significant differences between nurse' knowledge about cervical cancer risk factors or symptoms and screening methods regarding years of experience $(\mathrm{p}>0.05)^{(10)}$.

Regarding in service training: There were no significant association between knowledge of nursemidwives and in service training concerning pap smear as shown in (table 4B ). It was in agreement with study which stated the nurse - midwives $(73.5 \%)$ had received no in-service training (IST) on cancers that are specific to women, and $(66.7 \%)$ of those who did have training had received no information on PST during the training. It was determined that $(75.7 \%)$ of those who were trained had received their training from nurses. As vast a portion as $(87.5 \%)$ of the nurse-midwives were found not to have provided any information related to PST to healthy/ diseased individuals during clinical work ${ }^{(15)}$. A study reveals that nurses are in a quite suitable position to be the tools of change in the health care system and the whole public. They are working in all kinds of health care environments and in contact with all parts of the population; thus, without knowingly, they are acting as intermediaries of change. With these roles, they are in a key position in helping woman to gain positive knowledge and develop positive attitudes about health and changing the negative knowledge or attitudes as well. This phase is especially important because they act as role models towards the other members of the society with their knowledge about the diagnosis applications and applying these knowledge to real-life situations ${ }^{(12 \&}$ 16)

\section{CONCLUSION}

Nurse - midwives have unacceptable knowledge concerning pap smear, there were no statistical significant association between nurses -midwives' knowledge concerning pap smear and their demographic, reproductive variables, their experience, pap smear course and duration of training course.

\section{RECOMMENDATION}

1-Raising knowledge and awareness of nurse- midwives regarding Pap smear.

2-Installing in service educational program for nurse - midwives to upgrade the techniques necessary concerning Pap smear.

3-Initation and screening Pap smear for all health team including nurses- midwives.

\section{REFERENCES}

[1] Munoz M, Castellsague X, De Gonzalez AB, Gissmann L Chapter 1: HPV in the etiology of human cancer. Vaccine 2006; 24: 1-10.

[2] Adeleke NA, Komolafe JA. Knowledge, attitude and practice of cervical cancer screening among women of reproductive age group in Osogbo, South Western Nigeria. Sex Hlth Matters, 2007; 8:70-3.

[3] Zemheri E, Koyuncuer A. The importance of the pap smear test in the diagnosis of cervical cancers. Sürekli Tıp Eğitimi Dergisi, 2005; 14: 1-4.

[4] Türkistanlı EC, Soğukpınar N, Saydam BK et al. Cervical Cancer Prevention and early Detection - The Role of Nurses and Midwives. Asian Pac J Cancer Prev, 2003; 4: 15-21.

[5] Yücel U, Ceber E, Özentürk G. Efficacy of a training course given by midwives concerning cervical cancer risk factors and prevention. Asian Pac J Cancer Prev, 2009; 10:437-42.

[6] Yoshino Y, Ohta H, Kawashima M, et al. The knowledge of cervical cancer and screening adherence among nurses at a university- affiliated hospital in Japan. Kitasato Med J, 2012; 42: 6-14.

[7] Lundgren L E, Fisherman C, Widmark C et al. Midwives' Descriptions of Their Familiarly With Cancer. Cancer Nursing, 2000; 23: 392-400.

[8] Özdemir Ö, Bilgili N. Knowledge and Practices of Nurses Working in an Education Hospital on Early Diagnosis of Breast and Cervix. TAF Preventive Medicine Bull, 2010; 9: 605-12.

[9] Tchounga B, Jaquet A, Coffie P, Horo A, Sauvaget C, Adoubi I, Guie P, Sasco A, Ekouevi D, Cervical cancer prevention in reproductive health services: knowledge, attitudes and practices of midwives in Cote d'Ivoire, West Africa, BMC Health Services Research 2014; 14:165

[10] Ertem G. Awareness of Cervical Cancer Risk Factors and Screening Behavior Among Nurses in Rural Turkey. Asian Pac J Cancer Prev, 2009; 10: 735-8.

[11] Nganwai P, Truadpon P, Inpa C, Sangpetngam B, Mekjarasnapa M, Apirakarn M, et al. Knowledge, Attitudes and Practices vis-à-vis Cervical Cancer among Registered Nurses at the Faculty of Medicine, Khon Kaen University, Thailand. Asian Pac J Cancer Prev 2008; 9(1):15-8.

[12] Pınar G, Topuz Ş, An Ş et al. The knowledge levels of the women who have applied to the basket university Ankara hospital woman diseases and labor clinic about the hpv vaccine and cervix cancer. 
11.ulusal Jinekolojik oncology congress bindery ozet kitbag. Turk Jinekolojik Oncology Dergisi, 2008; 9: 183.

[13] Acikgoz A (2010). Risk levels of breast and cervix cancer and their relationship to the usage of early diagnosis services. İzmir, master thesis, dokuz eylül university health sciences Institute.

[14] National Cancer Institute Cancer Screening Consortium for Underserved Women, „Breast and cancer

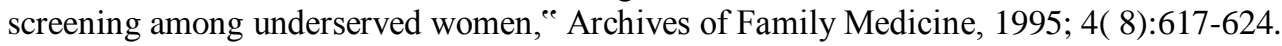

[15] Savas H, Taskin L : Determining Nurse - Midwives' Knowledge of the Pap Smear Test and their Rate of Being Tested in Turkey, Asian Pacific Journal of Cancer Prevention, 2011; 12 :1354.

[16] Coskun A, et al. A study which determines the demographical features of the women living in Austere neighborhood and their problems related to reproductive health. Sağlık via To plum Dergisi, 2001; 10: 22-9. 